\title{
An invasive alien bivalve apparently provides a novel food source for moulting and wintering benthic feeding sea ducks
}

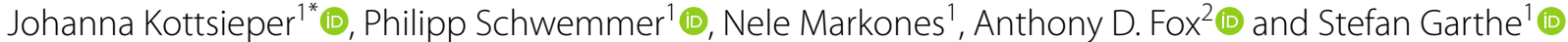

\begin{abstract}
Since its introduction from North America in the 1970s, the American razor clam Ensis leei (M. Huber, 2015) has successfully spread throughout North Sea coasts from Spain to Norway and the United Kingdom to the western Baltic. We investigated the distribution and abundance of this non-indigenous bivalve species as a potential novel food resource for common scoter Melanitta nigra (Linnaeus, 1758) along the eastern German North Sea coast. Highest densities of flightless moulting and wintering common scoters coincided with areas of high E. leei abundance. Other European studies showed common scoters extensively feed on E. leei. Even with these findings, it remains difficult to demonstrate convincingly that E. leei constitutes a major food source for common scoter in the German North Sea during their non-breeding season. However, our study suggests that $E$. leei has become an important prey item for internationally important concentrations of common scoters at large spatial scales.
\end{abstract}

Keywords: American razor clam, Ensis leei, Common scoter, German Bight, Melanitta nigra, Subtidal benthos

\section{Introduction}

Invasive species constitute one of the most serious threats to global marine biological diversity [1], potentially affecting ecosystem function, goods and services [2]. Being less susceptible, for instance, to endemic competitors, predators, diseases or parasites, they can become extremely abundant and dominate host systems [3]. However, it is known that some avian predators make use of aquatic alien bivalve species as novel food resources $[2,4]$.

Of several marine alien species introduced to the German North Sea since the early 18th century, some now only persist within limited ranges whereas others have become widespread $[5,6]$. The American razor clam (Ensis leei, see caption of Fig. 2 for taxonomic authorities)

*Correspondence: kottsieper@ftz-west.uni-kiel.de

${ }^{1}$ Research and Technology Centre (FTZ), Kiel University, Buesum, Germany

Full list of author information is available at the end of the article was first recorded in the German North Sea in 1979 [7], but now it occurs from Spain to Norway, the UK and the Western Baltic Sea [8]. It has rapidly increased in abundance and biomass over the last three decades in the Dutch [9] and more recently in the German North Sea $[10,11]$. Being common and highly abundant, E. leei potentially offers a profitable food resource for other species, such as benthic feeding fish and birds [12].

The common scoter (Melanitta nigra) is a sea duck species found in large numbers along the German North Sea coasts during moulting (July-September) and wintering seasons (October-March) [13]. Its distribution patterns are regularly monitored along the Dutch, German and Danish Wadden Sea coasts [1416]. Scoters predominantly feed on sedentary bivalve prey, which are highly abundant and easily accessible at any given site. They select mostly individuals ranging between 5 and $20 \mathrm{~mm}$, and sometimes up to $40 \mathrm{~mm}$, in length $[17,18]$. Recent studies report sea ducks such as common scoters actively feed on E. leei $[12,19,20]$. 
Although the local distribution patterns of both common scoters and E. leei have been described [21], few studies have attempted to demonstrate large-scale relationships between distributions of these avian predators and their benthic bivalve prey. Furthermore, few authors have demonstrated a direct connection by investigating the dietary contributions of $E$. leei by analysing stomach contents of dead scoters [but see 20-22].

To investigate the potential importance of $E$. leei as a food resource, we studied its distribution pattern in the German Bight. We also mapped the distribution patterns of moulting (i.e. flightless) and wintering common scoter. Based on these distributions, we raised the following hypotheses:

1. High(est) densities of common scoters are found in areas with high(est) densities of E. leei.

2. Where present, E. leei is more abundant compared to other native bivalve species and can thus contribute a major share to common scoter diets.

\section{Materials and methods Study areas}

The study areas were located in the sublitoral German North Sea along the coast of Schleswig-Holstein (see Fig. 1). These areas were consistently used by moulting and wintering common scoter (FTZ unpublished data). The moulting area covered $860 \mathrm{~km}^{2}$ in the southern German North Sea extending from Friedrichskoog $\left(54^{\circ}\right.$ $\left.2^{\prime} \mathrm{N}, 8^{\circ} 34^{\prime} \mathrm{E}\right)$ to Westerheversand $\left(54^{\circ} 23^{\prime} \mathrm{N}, 8^{\circ} 33^{\prime} \mathrm{E}\right)$ with water depths ranging from 1 to $16 \mathrm{~m}$. The wintering area was located west of the island Sylt covering $490 \mathrm{~km}^{2}$ with water depths ranging from 5 to $17 \mathrm{~m}$. Both areas were within the twelve nautical mile zone. Both regions are located in protected areas designated by the Habitats Directive and the Birds Directive, as well as being listed as Ramsar sites [23].

\section{Ensis leei distribution}

Overall, 319 benthos samples were taken with a $0.1 \mathrm{~m}^{2}$ van Veen grab in both areas; 263 samples were collected in the moulting area during five cruises in 2015-2017 and 56 samples were collected in the wintering area during one cruise in 2018. Samples were taken based on grids (either a $5 \times 5 \mathrm{~km}$ grid or a random stratified design) with three replicates at each sampling station. Collected bivalves were sieved through a $2 \mathrm{~mm}$ mesh and frozen in zip lock bags at $-20{ }^{\circ} \mathrm{C}$ for subsequent analysis. E. leei individuals were measured with callipers to the nearest

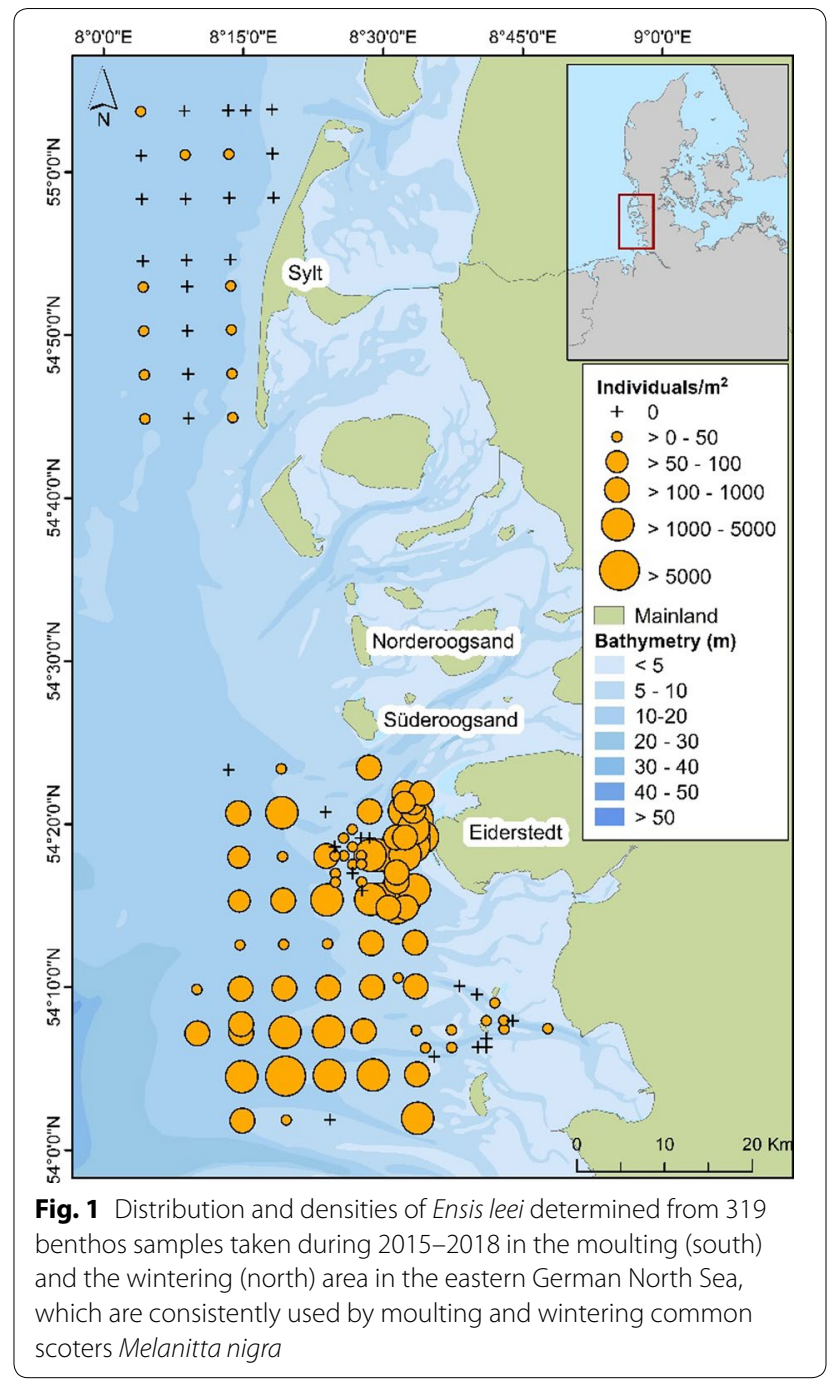

$\mathrm{mm}$ and their numbers were converted to density (number of individuals per $\mathrm{m}^{2}$ expressed as mean \pm standard deviation). To test for statistical differences in E. leei frequencies between sampling stations and areas, a Chi square test was performed in R [24].

\section{Common scoter distribution}

Data from ship and aerial Seabirds at Sea (SAS) surveys conducted by the Research and Technology Centre (FTZ) during the moulting and wintering periods of common scoter were used to generate distribution patterns and calculate common scoter densities (individuals per $\mathrm{km}^{2}$ summarised for all surveys and rastered by $5 \times 5 \mathrm{~km}$ grid squares). The surveys were implemented by the FTZ within a regular offshore seabird monitoring on behalf of the Schleswig-Holstein Agency for Coastal Defence, National Park and Marine Conservation-National Park 
Authority. Surveys were carried out following internationally standardized Seabirds at Sea methods [25] based on line transect methodology including distance sampling [26]. All aerial surveys had a fixed design with seven nearly $\mathrm{N}-\mathrm{S}$ transects parallel to the coast. The four innermost transects were spaced at a $3 \mathrm{~km}$ interval, the remaining three were spaced at $6 \mathrm{~km}$ intervals. Surveys were performed from a high-winged twin-engine Partenavia P-68 with bubble windows at a flight altitude of $76 \mathrm{~m}(250 \mathrm{ft})$ and a cruising speed of $185 \mathrm{~km} \mathrm{~h}^{-1}(100$ knots). The occurrence of birds was recorded within $388 \mathrm{~m}$ wide transects running parallel to the flight route of the observation platform. Ship based counts were either conducted parallel to the benthos sampling cruises or data were taken from regular ship based monitorings. Birds were recorded within a $300 \mathrm{~m}$ wide transect running parallel to the keel line of the observation vessel. Due to gaps in data, caused by either bad weather conditions or unavailability of ship/aircraft, data from 20152017 was combined. To match the benthos sampling areas, distribution maps are shown for the SchleswigHolstein North Sea coast.

\section{Results}

\section{Ensis leei distribution}

Ensis leei was more widespread and occurred at higher densities in the southern study area $(1003.9 \pm 1680.7$ ind $\mathrm{m}^{-2}$, exceeding 10,000 ind $\mathrm{m}^{-2}$ in some samples) than in

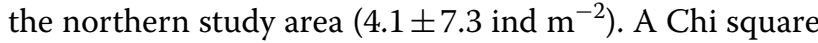
test revealed statistically significant differences in the distribution between both areas $(p \leq 0.001)$. E. leei densities for all sampling stations in both areas are shown in Fig. 1. E. leei was present at almost all sampling stations in the southern study area (see Fig. 2a), but was less prominent $(p \leq 0.001)$ in the northern study area (Fig. 2b). Where present, E. leei dominated the benthic species composition in almost every single sample in the southern study area.

\section{Common scoter distribution}

During the time of moulting, common scoters occurred in small numbers along the entire eastern German North Sea coast with highest densities west of the islands Süderoogsand ( 810 ind $\mathrm{km}^{-2}$ ) and south west of the Eiderstedt peninsula (219 ind $\mathrm{km}^{-2}$, Fig. 3). Fewest individuals were observed in the northern parts west of the island of Sylt and in offshore areas. This distribution corresponded closely with areas of highest $E$. leei abundance,

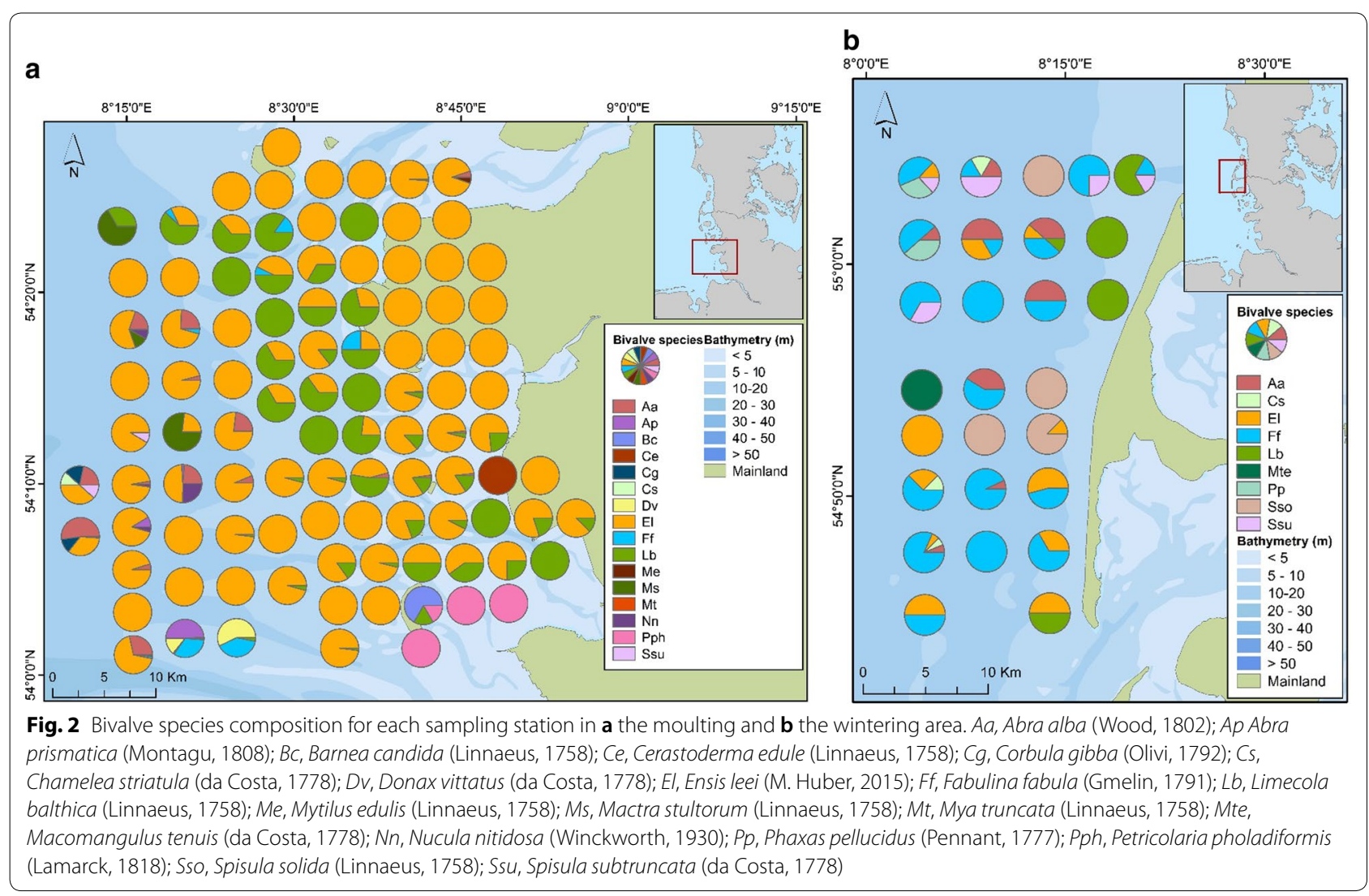




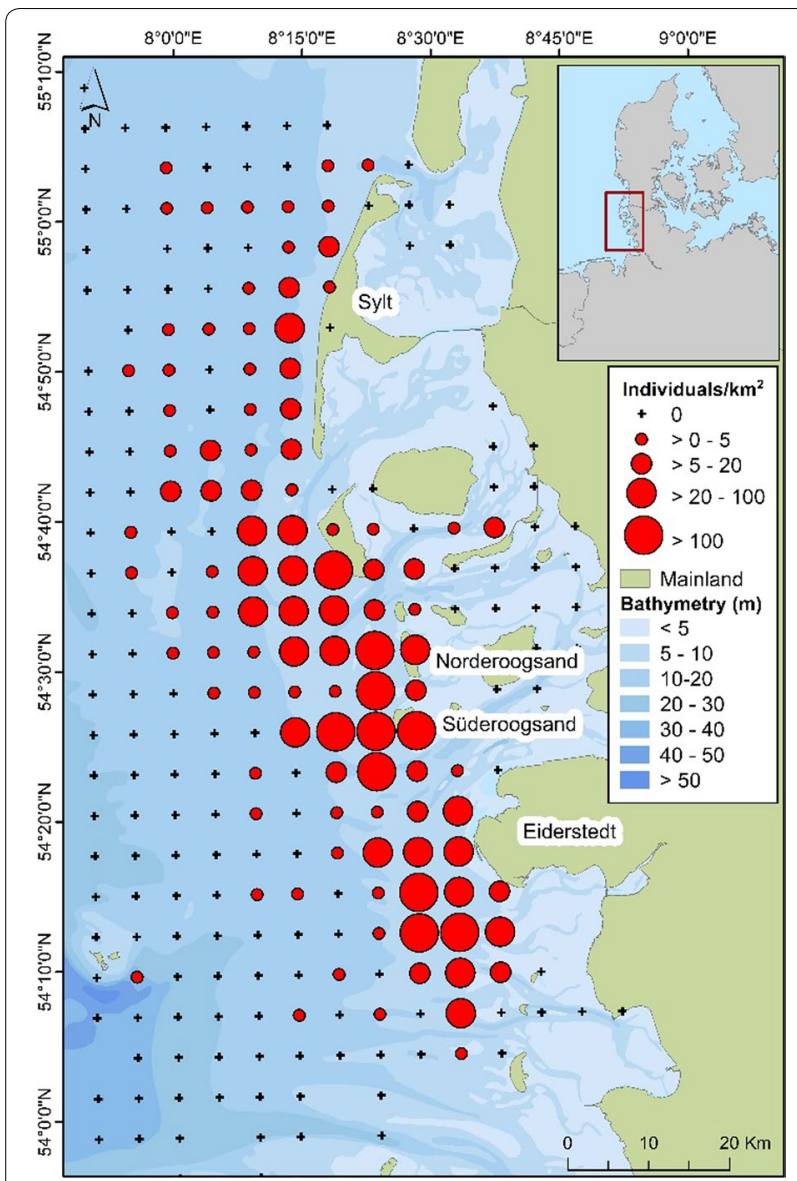

Fig. 3 Distribution patterns of common scoter Melanitta nigra in the German North Sea during the moulting season given as individuals $\mathrm{km}^{-2}$. The map shows data from June to September in the years 2015-2017. To calculate densities, the number of birds was summed for all surveys

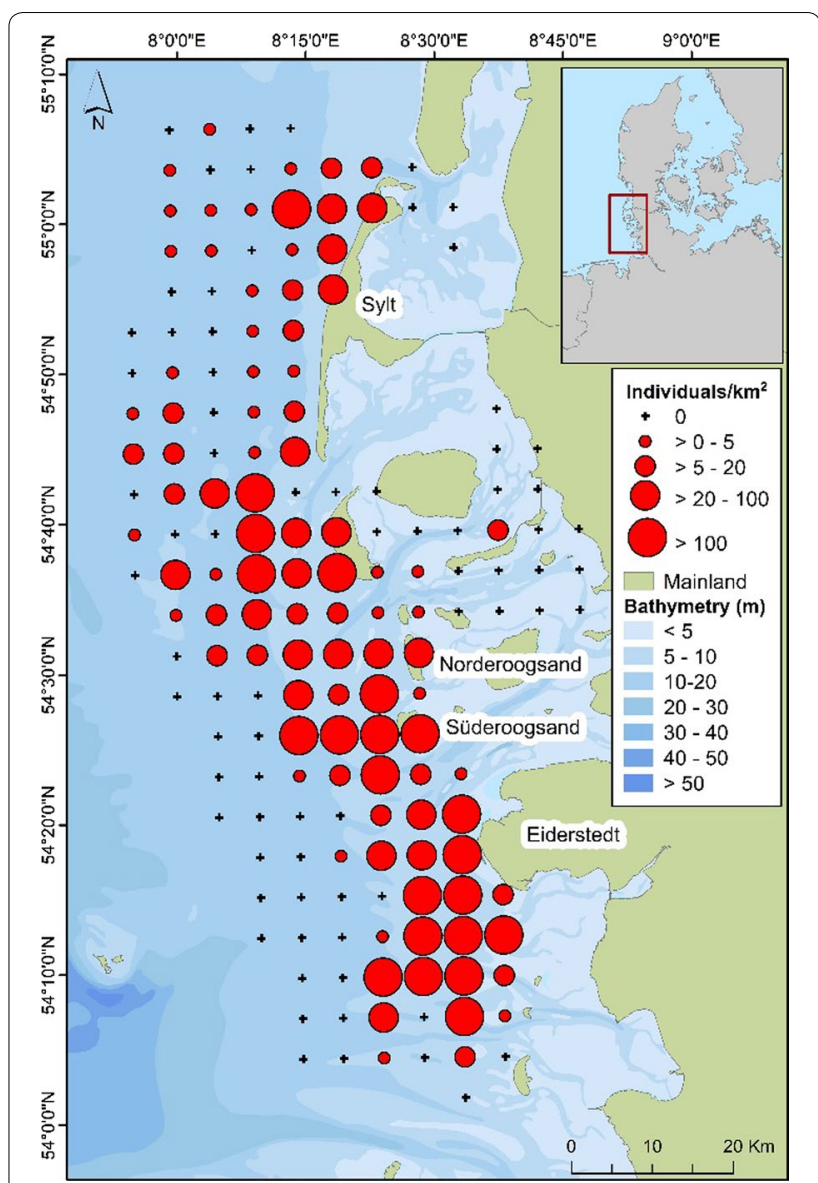

Fig. 4 Distribution of the common scoter Melanitta nigra in the German North Sea during the wintering season given as individuals $\mathrm{km}^{-2}$. The map shows data from the months December to February in the years 2015-2017. To calculate densities, the number of birds was summed for all surveys including areas where this species dominated the benthic community. Additionally, areas of highest scoter abundance were observed at the sites with the highest densities of small $(<2 \mathrm{~cm}$ in length) E. leei individuals.

During winter, common scoters were more dispersed along the eastern German North Sea coast and located further offshore (Fig. 4). Higher densities were observed west of Sylt, particularly along the northern end and highest densities were found southwest of the Eiderstedt peninsula (618 ind $\mathrm{km}^{-2}$ ) and close to Süderoogsand (560 ind $\mathrm{km}^{-2}$ ). Again, the occurrence of scoters west of the Eiderstedt peninsula matched the locations with highest E. leei abundance.

\section{Discussion}

Our findings show that common scoters occur along the German North Sea coast in areas where E. leei is extremely abundant. This pattern is particularly evident during the moulting period when these birds cannot fly and therefore their surveyed distributions reflect their distribution in relation to feeding grounds. Highest scoter abundances during moult and winter occurred in the southern German North Sea, corresponding to areas of highest $E$. leei densities based on our benthos sampling. Common scoter typically feed on bivalves $<60 \mathrm{~mm}$ long [18], although single scoters have been regularly observed feeding on E. leei individuals $>90 \mathrm{~mm}$ as well (I.K. Petersen personal communication). Kottsieper et al. [11] found that the E. leei individuals sampled in both the moulting and wintering fell within the same size class distributions. Particularly in the moulting area, high densities of small E. leei specimens were detected. 
The dominance, extent and available size class distribution of E. leei throughout the German North Sea in areas with moulting and wintering common scoters suggests this species could potentially provide a profitable food resource to this sea duck species in these areas.

Leopold and Wolf [19] were the first to describe that scoters actively feed on the American razor clam. Prior to this study, Abra alba, Cerastoderma edule, Limecola balthica, Mya arenaria, Mytilus edulis and Spisula subtruncata, amongst others, were listed as the most important prey items [18]. Studies from the German North Sea, however, showed that all these species had lower flesh to shell ratios compared to E. leei, so this species is not just most abundant but also of superior food quality compared to native bivalves in the area [11,21]. A recent study from Fijn et al. [16] stated that common scoters residing in the Dutch Wadden Sea preferably feed on Spisula subtruncata, yet the high abundances of E. leei provides enough resources to fall back on. Freudendahl and Jensen [22] reported that all 26 common scoters shot at Horns Rev in the Danish North Sea had been feeding on E. leei. In a more recent study, Schwemmer et al. [21] analysed 88 stomachs of scoters found dead along the German North Sea coast, showing that E. leei was the most common species in all stomachs. However, assessing the importance of a prey by analysing stomach contents can be difficult. Stomachs from birds found dead on the shore inevitably originate from weakened individuals that have died of disease or were in poor condition and likely have emptied their stomachs long before being washed ashore. Collecting birds by shooting does not necessarily resolve this issue. Thirty wintering common scoter shot in the Wadden Sea and 59 moulting specimens shot in Aalborg Bugt (Denmark) had nearly empty stomachs, suggesting that birds may potentially feed most actively at night [27, 28].

It is extremely challenging to prove that common scoters have switched from native prey to aggregate during moult and winter periods in a feeding response to $E$. leei density and abundance along German North Sea coasts. Sampling of benthos occurs at a scale $\left(<1 \mathrm{~m}^{2}\right)$, which is inappropriate to explain the distribution and abundance of common scoter that assort themselves in many thousands of individuals throughout more than $3000 \mathrm{~km}^{2}$ of marine habitat off the German Wadden Sea. As discussed above, there are limitations and challenges associated with analysing the stomach contents of dead birds to assess the relative importance of $E$. leei in the moult and wintering diet of individuals and the population as a whole. The flesh to shell ratio of $E$. leei is superior to most other sympatric bivalve species [11] making it highly suitable prey for scoters. However, its attractiveness as prey is dependent on its abundance and size class distribution relative to other molluscs in the same sediment and the depth of the water column through which the sea ducks have to dive to obtain their prey (which determines the energetic costs of obtaining such prey). Spat settlement, mass die-offs and predation by fish and sea ducks all affect bivalve abundance and size class distributions within and between seasons. In marine systems, therefore, it is impossible to demonstrate a meaningful aggregative response of common scoters to E. leei. However, we would contend that based on data presented here, moulting (and therefore largely immobile) common scoters occur in very high densities over substrates where the benthos is composed almost exclusively of E. leei. We therefore assume that this highly profitable species contributes a major share to the scoter diet. The distribution and abundance of $E$. leei likely explains the distribution and abundance of the common scoters in their moulting and wintering areas at the present time. Modelling the distribution of common scoter in connection with the $E$. leei distribution would give us more insight into the relationship between both species.

Ensis leei also likely explains the distribution of common scoters elsewhere and at greater geographical scales. Houziaux et al. [29] reported high recruitment of juvenile E. leei in spring 2007 in the Belgian Wadden Sea and annual monitoring shows the species has been increasing in the Dutch Wadden Sea since 2010 [30]. In the German North Sea, Schwemmer et al. [21] found high densities along the North Frisian Island coasts. In a previous study, Dannheim and Ruhmohr [10] found high densities west of Sylt and Amrum as well as Eiderstedt. All these regions support common scoters and in many areas their numbers are increasing. Results from detailed benthos studies in German North Sea common scoter moulting areas demonstrated remarkably high abundances of E. leei [11], which have correlated with increasing densities of moulting and wintering scoter numbers in this area during the last 3 years (FTZ unpublished data).

Common scoter distribution and abundance are regularly monitored throughout the annual cycle along Wadden Sea coasts [14]. However, we lack spatially and temporally explicit monitoring of benthic communities and the seasonal size class distributions of their components to help interpret their attractiveness and relative importance to feeding common scoters. Annual benthos monitoring occurs only in the Netherlands [30] and the few studies of E. leei distributions in the German North Sea have restricted spatial scales [10]. However, Schwemmer et al. [21] and Kottsieper et al. [11] have contributed new and more detailed information of recent years. Nevertheless, demonstrating the importance of E. leei as food for common scoters remains difficult as long as aerial seabird and benthos surveys are 
not performed simultaneously or at similar spatial scales that can account for shifts in patterns and seasonal differences. More detailed information on the dietary composition (including oesophagus, gizzard and gut contents) is needed to improve our understanding of common scoter diets. The results presented here confirm other studies showing that along North Sea coasts, E. leei has become an important element of the diet of common scoters during the critical moult and winter periods at large (i.e. thousands of square kilometres) spatial scales, including within EU Birds Directive protected areas designated for internationally important aggregations of this sea duck species.

\section{Acknowledgements}

We are particularly grateful to the research institutions Helmholtz Zentrum Geesthacht and the Alfred-Wegener-Institut Wadden Sea Station Sylt, who provided us with their research vessels Ludwig Prandtl and Mya I/ respectively, as well as to the crews of those research vessels who helped us collecting the benthos samples. Additionally, we would like to thank all the colleagues who supported us in conducting the seabirds at sea surveys.

\section{Authors' contributions}

JK and PS were responsible for planning and conducting the study. JK carried out sample and data analysis and drafted the manuscript. NM is responsible for the Seabirds at Sea monitoring. All authors read and approved the final manuscript.

\section{Funding}

The study was part of the project STopP funded by the German Ministry for Science and Education (BMBF, Grant Number 03F672B). Seabirds at Sea survey data was collected within the offshore seabird monitoring programme in the Schleswig-Holstein North Sea carried out on behalf of the Schleswig-Holstein Agency for Coastal Defense, National Park and Marine Conservation-National Park Authority.

\section{Availability of data and materials}

All data analysed and used in this study are published in this article as well as partly in "Comparison of bivalve communities between moulting and wintering areas used by Common Scoter Melanitta nigra in the German North Sea" by Kottsieper J, Schueckel U, Schwemmer P, Fox AD, Garthe S (2019) published in Estuar Coast Shelf Sci. Since this study is part of a still ongoing Ph.D. thesis by the first author, data used and analysed in this study is only available from the corresponding author on reasonable request.

\section{Ethics approval and consent to participate}

Not applicable.

\section{Consent for publication}

Not applicable.

\section{Competing interests}

The authors declare that they have no competing interests.

\author{
Author details \\ ${ }^{1}$ Research and Technology Centre (FTZ), Kiel University, Buesum, Germany. \\ ${ }^{2}$ Department of Bioscience, University of Aarhus, Rønde, Denmark.
}

Received: 18 February 2019 Accepted: 6 December 2019

Published online: 19 December 2019

\section{References}

1. Molnar JL, Gamboa RL, Revenga C, Spalding MD. Assessing the global threat of invasive species to marine biodiversity. Front Ecol Environ. 2008;6:485-92. https://doi.org/10.1890/070064.

2. Bax N, Williamson A, Aguero M, Gonzalez E, Geeves W. Marine invasive alien species: a threat to global biodiversity. Mar Policy. 2003;27:313-23. https://doi.org/10.1016/S0308-597X(03)00041-1.

3. Grosholz ED, Ruiz GM, Dean CA, Shirley KA, Maron JL, Connors PG. The impacts of a nonindigenous marine predator in a California Bay. Ecology. 2000;81:1206-24. https://doi.org/10.1890/0012-9658(2000)081\%5b120 6:TIOANM\%5d2.0.CO:2

4. Werner S, Moertl M, Bauer HG, Rothhaupt KO. Strong impact of wintering waterbirds on zebra mussel (Dreissena polymorpha) populations at Lake Constance Germany. Freshw Biol. 2005;50:1412-26. https://doi.org/10.11 11/j.1365-2427.2005.01411.x.

5. Gollasch S. Overview on introduced aquatic species in European navigational and adjacent waters. Helgoland Mar Res. 2006;60:84-9. https://doi. org/10.1007/s10152-006-0022-y.

6. AquaNIS Editorial Board. Information system on aquatic non-indigenous and cryptogenic species. World Wide Web Electronic Publication. 2015. http://www.corpi.ku.lt/databases/aquanis.Version2.36+. Accessed 30 July 2018.

7. Cosel R, Dörjes J, Mühlenhardt-Siegel U. Die Amerikanische Schwertmuschel Ensis directus (Conrad) in Der Deutschen Bucht: I. Zoogeographie Und Taxonomie Im Vergleich Mit Den Einheimischen Schwertmuschel-Arten [The American Jackknife Clam Ensis directus (Conrad) in the German Bight: I. Zoogeography and Taxonomy in Comparison with the Native Jackknife and Razor Clams'] Senckenberg Marit 1982;3/4:147173. http://www.vliz.be/en/imis?refid=115578.

8. Gollasch S, Kerckhof F, Craeymeersch J, Goulletquer P, Jensen K, Jelmert A, Minchin D. Alien species alert: Ensis directus. Current status of invasions by the marine bivalve Ensis directus. ICES Coop Res Rep. 2015;323:1-36.

9. Dekker R, Beukema JJ. Long-term dynamics and productivity of a successful invader: the first three decades of the bivalve Ensis directus in the Western Wadden Sea. J Sea Res. 2012;71:31-40. https://doi.org/10.1016/j. seares.2012.04.004

10. Dannheim J, Rumohr H. The fate of an immigrant: Ensis directus in the Eastern German Bight. Helgoland Mar Res. 2012;66:307-17. https://doi. org/10.1007/s10152-011-0271-2.

11. Kottsieper J, Schueckel U, Schwemmer P, Fox AD, Garthe S. Comparison of bivalve communities between moulting and wintering areas used by common scoter Melanitta nigra in the German North Sea. Estuar Coast Shelf Sci. 2019. https://doi.org/10.1016/j.ecss.2019.106398.

12. Tulp I, Craeymeersch J, Leopold M, van Damme C, Fey F, Verdaat H. The role of the invasive bivalve Ensis directus as food source for fish and birds in the Dutch Coastal Zone. Estuar Coast Shelf Sci. 2010;90:116-28. https:// doi.org/10.1016/j.ecss.2010.07.008.

13. Mendel B, Sonntag N, Wahl J, Schwemmer P, Dries H, Guse N, Müller S, Garthe S. Artensteckbriefe von See-and Wasservögeln Der Deutschen Nord-And Ostsee: Verbreitung, Ökologie And Empflindlichkeiten Gegenüber Eingriffen in Ihren Marinen Lebensraum. Bundesamt f. Naturschutz, 2008

14. Markones N, Garthe S. Monitoring von Seevögeln Im Offshore-Bereich Der Schleswig-Holsteini-Schen Nordsee Im Rahmen von NATURA 2000 in Den Jahren 2004 bis 2009. Corax. 2011;22:11-50.

15. Pihl S, Holm TE, Clausen P, Petersen IK, Nielsen RD, Laursen K, Bregnballe T, Søgaard B. Fugle 2012-2013 NOVANA. Videnskabelig Rapport 2015;125 fra DCE-Nationalt Center for Mijø og Energi. Aarhu: Aarhus Universitet.

16. Fijn RC, Leopold MF, Dirksen S, et al. Een onverwachte concentratie van Zwarte Zee-eenden in de Hollandse kustzone in een gebied met hoge dichtheden van geschikte schelpdieren. Limosa. 2017;90:97-117.

17. Madsen FJ. On the food habits of the diving ducks in Denmark. Dan Rev Game Biol. 1954;2:159-266.

18. Fox AD. Diet and habitat use of scoters Melanitta in the Western Palearctic - a brief overview. Wildfowl. 2004;54:163-82.

19. Leopold MF, Wolf P. Zee-Eenden Eten Ook Ensis. Nieuwsbrief Nederlandse Zeevogelgroep. 2003;4:5.

20. Leopold MF, Spannenburg PC, Verdaat HJP, Kats RKH. Identification and size estimation of Spisula subtruncata and Ensis americanus from shell fragments in stomachs and faeces of common eiders Somateria mollissima and common scoters Melanitta nigra. In: Kats RKH, editor. Common 
eiders Somateria mollisssima in the Netherlands The rise and fall of breeding and wintering populations in relation to the stocks of shellfish. Groningen: Rijksuniversiteit Groningen (Scientific Contributions 19); 2007. p. 63-85.

21. Schwemmer P, Volmer H, Enners L, Riemers HC, Binder K, Horn S, Eskildsen K, Adler S, Fox AD, Garthe S. Modelling summer distribution patterns of common scoters (Melanitta nigra) by its most important prey species, the razor clam (Ensis directus), and hydrodynamic parameters. Estuar Coast Shelf Sci. 2019;225:106260. https://doi.org/10.1016/j. ecss.2019.106260

22. Freudendahl AS, Jensen KT. Population dynamics of the American razor clam (Ensis americanus) at Horns Rev. Report by University of Aarhus, Department of Marine Ecology; 2006.

23. Krause J, Wollny-Goerke K, Boller F, Hauswirth M, Heinicke K, Herrmann C, Körber P, Narberhaus I, Richter-Kemmermann A. The German marine protected areas in the North Sea and Baltic Sea. Natur Und Landschaft. 2011;86(9):397.

24. R Core Team. R: A language and environment for statistical computing. R Foundation for Statistical Computing, Vienna, Austria. 2017. https:// www.R-project.org/.

25. Camphuysen CJ, Fox AD, Leopold MF, Petersen IK. Towards standardised seabirds at sea census techniques in connection with environmental impact assessments for offshore wind farms in the U.K. COWRIE-Report BAM-02-2002. Royal Netherlands Institute for Sea Research, Texel; 2004.
26. Buckland ST, Rexstad EA, Marques TA, Oedekoven CS. Distance sampling: methods and applications. New York: Springer; 2015.

27. Fox AD, Hartmann P, Petersen IK. Body mass and organ size change during wing moult in common scoter. J Avian Biol. 2008;39:35-40. https:// doi.org/10.1111/j.2007.0908-8857.04135.x.

28. Skov H, Durinck J, Erichsen A, Kloster RM, Møhlenberg F, Leonhard SB. Horns Rev II offshore wind farm food basis for common scoter: baseline studies 2007-08. Final Report by Orbicon/DHI/Marine Observers to DONG Energy A/S, Copenhagen; 2008

29. Houziaux JS, Craeymeersch J, Merckx B, Kerckhof F, van Lancker V, Courtens W, Stienen E, Perdon J, Goudswaard PC, van Hoey G, Vigin L, Hostens K, Vincx M, Degraer S. 'EnSIS' - Ecosystem Sensitivity to Invasive Species. Final Report. Brussels: Belgian Science Policy Office 2012-Research Programme Science for a Sustainable Development; 2011, p. 105

30. Troost K, Perdon KJ, van Zwol J, Jol J, van Asch M. Schelpdierbestanden in de Nederlandse kustzone in 2017. IJmuiden: Stichting Wageningen Research, Centrum voor Visserijonderzoek (CVO); 2017. https://library.wur. nl/WebQuery/wurpubs/526296.

\section{Publisher's Note}

Springer Nature remains neutral with regard to jurisdictional claims in published maps and institutional affiliations.
Ready to submit your research? Choose BMC and benefit from:

- fast, convenient online submission

- thorough peer review by experienced researchers in your field

- rapid publication on acceptance

- support for research data, including large and complex data types

- gold Open Access which fosters wider collaboration and increased citations

- maximum visibility for your research: over $100 \mathrm{M}$ website views per year

At BMC, research is always in progress.

Learn more biomedcentral.com/submissions 